\title{
USING GEOPOLITICS IN THE COMPARATIVE ANALYSIS OF TWO INTERNATIONAL SYSTEMS BASED ON FACTORS CONSIDERED RELEVANT
}

\section{Anca DINICU}

\author{
“Nicolae Bălcescu" Land Forces Academy, Sibiu, Romania \\ anca_dinicu@yahoo.com
}

\begin{abstract}
The international scene is still modeled on the states' interests, despite the challenges of non-state actors, whose international policy intervention can not be described as new. The state still continues to play a central role in shaping the international system, even if it is forced to act in an environment where large corporations are designing many of the national economies of states whose nationality they do not have, and non-governmental organizations are at the outskirts of an emerging global civil society, which could jeopardize the state's right and obligation to prevent injustice, and considering that at the global level there is no entity able to issue regulations in this regard, all of which amid testing international governance models. Looking retrospectively, during the Cold War, the state was much stronger and the threats which it had to face were characterized by a much higher degree of predictability.

This paper aims to analyze the contemporary international system by reference to that specific to the Cold War, based on factors considered relevant, the objective being to identify the possibility of turning the present international system to a new Cold War.
\end{abstract}

Keywords: geopolitics, power, international system, historical factor, ideological factor.

\section{Introduction}

It is obvious today that geopolitics is beginning to regain its authority as a tool for deciphering and explaining present and past events by reconsidering its analytical importance following the elimination of its destructive association with the actions of Nazi Germany. Geopolitics is thus a useful way of analyzing international relations in their dynamics by evaluating the determinants of events in their specific context and explaining the consequences of different actions not only at the level of primary actors (i.e. those directly involved in the event), but also at the level of secondary actors (those who, although not directly involved, have, as a result of their own interests, a stake in the evolution of the situation in one direction or another). Geopolitics therefore considers the rivalries of power in terms of attracting or maintaining a geographical space in a certain area of influence. Geopolitical analysis is related to the territory because it is concerned with the way in which geography influences international politics (but not in a deterministic sense), the changes that international politics generate at the level of geography, the history of relations between states, as well as their interests, thus trying to identify possible developments on the international scene. Geopolitics operates with the same factors, regardless of the moment of analysis or the historical time in which the analyzed event is placed, but these factors are of different importance, the context being that of prioritizing them. From the perspective of this analytical approach (i.e. the need to carry out the comparative analysis between 
two international systems of global scope), the geopolitical evolution of the international system, based on the manifestations of power, is based on both the following factors: historical and ideological.

\section{Method}

In order to write this paper, the comparative analysis proved to be a very useful method and it was applied on data and information gained on the base of empirical observation of the selected events.

\section{Analysis of factors considered relevant}

According to the philosophy of this paper, the international system is the product of the interaction of the states of the world, the nature of this interaction being determined not by the sovereignty of states but by the power abilities that they possess and through which they seek to attain their interests. This results in a network of relationships that are structured on the basis of rules, sometimes amoral, but definitely well-defined, which in turn generates effects both on the domestic policy of states and on international politics.

\subsection{The historical factor}

The emergence of a new global international system is the result of a historical context that leads to the emergence of a new hierarchy of power. In both cases taken into account (the system specific to the Cold War period and the post-Cold War system), each system emerged from a confrontation: the first, in the form of a proper war (the Second World War), and the second, in the form of a "warm peace" (the Cold War).

Even before the end of the Second World War, it became obvious that the alliance formed for Hitler's defeat would not work when peace will have been established. The February 1945 Yalta Conference was to decide on the first geopolitical movements of the Americans and the Soviets along the line of geopolitical moves that would define the Cold War period - the center of gravity of redesigning the political map of the world would thus be represented by Germany's territorial division, that is, the division of Germany and Berlin into the four occupation areas after the war, namely four sectors.

As for the post-Cold War system, it was rather the result of a confrontation not won by Americans but lost by the Russians, as a consequence of the implosion of the Soviet Union due to its incapacity for internal transformation and its functioning based on a logic that had become anachronistic. And the geopolitical vacuum created especially in Central and Eastern Europe would be, in the first instance, overwhelmed by the rapid reorientation, first of all at declarative level, of the foreign policy of the states in the area, which in fact constituted an invitation addressed to Western states to cover the power vacuum created.

\subsection{The ideological factor}

There is currently a considerable amount of suspicion or restraint concerning the concept of ideology, often associated with the resonance of the suffix "ism" communism, nationalism, anarchism, fascism, Islamic fundamentalism, but also liberalism. But, irrespective of the message, the impact of political, cultural or religious beliefs and values on the organization and functioning of a society, at the mental level, ideology is perceived as a bundle of artificially grounded ideas, located on a level parallel to the daily life of the individual and used in a manipulative manner "by the powers that be and the powers that want to be [1].

The Cold War was, first and foremost, an ideological confrontation, the national interest of each of the two super powers having an ideological footprint needed to justify the pursued ambitions and policies promoted. The fact that the Cold War would have an ideological trait is a perfect result of the context that led to cooperation between the Allies in the Second World War and which was based not on a common vision on a solid and lasting project on the 
organization of the system, but a common interest of both political and extremely pragmatic nature. However, how can two states that are defined by completely different ideologies cooperate? The answer lies in the national interest and foreign policy as a tool for its realization. As noted by the remarkable American political scientist and diplomat Henry Kissinger, "the common geopolitical interest is a strong bond" [2], which means that national interest can be freed from the possible ideological imprinting and put into practice, including through partnership with states that naturally should not resonate with. The ideologies referred to when talking about the Cold War framework are liberalism, communism and fascism, but also nationalism (as an extension of $19^{\text {th }}$ century political thinking). Of these, however, the first two stand out, marking the history of a not only troublesome $20^{\text {th }}$ century, but also of a century in which the countdown of the years stopped at 70 (1919-1989).

With the end of the Cold War, there also emerged the theory that it was "the end of ideologies", too. Rather, it would be an end to the ideological confrontation, because as one of the super-powers of the Cold War survived (the United States of America), so did the ideology promoted by it, which continued not only to exist but also to extend its geographical coverage, even attempting to establish an international order based on (liberal) democracy, market economy, and human rights and freedoms. It may be considered that the project failed, the world economic crisis that broke out in 2008 in the world's most developed economy seriously shaking the economic foundation of the desired order, and causing the state to drastically intervene in national economies for the purpose of saving them, but also for saving its citizens. At that time some voices claimed if not of returning to Marx and Engels, at least reconsidering Keynes's way of thinking.

Anyway, by being ideological defeated and considering the new international context, Russia was forced to make some changes related with the state functioning and democratization. But the new values have been improperly implemented and the results seems to be a "hybrid version of democracy, with an oligarchic governance structure and limits on individual freedoms" [3].

\section{Interpretation of the results obtained from the analysis of the two factors}

The comparative analysis in the field of international relations carried out in the present case through the use of geopolitics as a means of introspection of events offers the possibility of understanding the dynamics and the meaning of the evolution of the international system, a system in which the State, despite the competition from other types of actors, remains the main determinant of global political architecture.

\subsection{The historical factor}

Obviously, both international systems are rooted in the transformations generated mainly by the end of an era, and first of all in the emergence of a decisive shift in the global power structure aimed to establish a new order.

If, at the end of the Second World War, the system appeared to have a bipolar structure as a result of the appearance of only two world powers to which other state actors were related to, despite the existence of other important states (if we take into account only the Great Britain, France and China, the other three states benefiting from the right of veto within the Security Council), at the end of the Cold War, the newly born system was originally characterized by unipolarity (the United States becoming a hyper-power by the disappearance of its rival) becoming, in a relatively short time multipolar by the assertion of certain states with pretensions to participate in the global affairs management mechanism, even if the extent of their action was feasible only at regional level. The genesis of the multipolar system was possible amid the loss of Americans' credibility to some states and the deterioration of its image of invincibility as a 
result of the terrorist attacks of September 2001. It was the time when the international balance was between "what was preferable from the ideological point of view" and "what was desirable to ensure success". However, this was not the case for Moscow, which continued to be perceived as a world power only from the point of view of the nuclear factor; instead, Washington maintained its supremacy by gathering four important attributes of power - economic, military, cultural and technological - even if in recent years these have been undergoing serious challenges from regional powers, some of them emergent.

The trajectory of the two states' evolution within the bipolar system and the position occupied by each of them within the multipolar system can be a starting point in the global hegemony - leadership binomial analysis. States constituted in global and regional power centers can guide the evolution of the international system in the direction of cooperation and development, including through reforming their own societies and rethinking governance at national level. As shown in the literature, "the really great changes that define the transformations of an era are caused by changes in the nature of the dominant units" [4].

\subsection{The ideological factor}

Generally speaking, the utility of ideology for the political decision-maker is obvious, because, through the patterns it imposes, suggests a certain direction of interpretation and perception of the world. It thus becomes a useful tool for the public policy maker in his attempt to explain, justify and get public support for his/her actions. Therefore, ideology would legitimize the political power of the dominant unity at the level of the international system or the dominant group at the internal level of the (state) analysis unit. However, there are situations (as it has already been pointed out) when the political decision aims exclusively at the goal, disregarding the means.

As regards the end of ideologies, this theory was strongly promoted by the American sociologist and political scientist Francis Fukuyama, who, amid the dissolution of communist ideology, supported the triumph of liberalism as the ultimate ideology in the evolution of humanity [5]. But as "the end of history" meant the end of a historical age, also the idea of the end of ideologies could mean their termination in their classical sense, a need to reinvent them according to the determinations of the contemporary era so that not only states but also individuals to understand the context which they are part of, most of them independent of their sovereignty and will, and to explain apparent spontaneous phenomena and processes, which were inconceivable in a previous age.

Governments will continue to define themselves politically, embracing a doctrinal cloak absolutely necessary to guide ideas and policies, ensuring as much as possible the flow of processes and explaining determinations. The lack of current citizens' confidence in the political parties, the (current) chaos of the classical parties amid the exhaustion of their mobilizing state as a result of the strident and ineffective promotion of their belonging to the political spectrum (left or right), the appearance of "providential" people able to save the nations of the supranational claw, the struggle with everything that goes beyond the comfortable level of understanding and knowledge, all these and many others are not the product of these days, but of those of the beginning of the new system, some of which having even more distant origins. The current system has failed to generate a relatively stable structure of power, including recognized and accepted, state of being that favored the exaggeration of freedom (in the sense of breach of norms), excessive privatization of earnings, and an equally excessive socialization of losses.

Given the complexity of the current international context, political discourse and theorizing of attitudes will fall under the same suffix "ism", this time talking of 
extremism, populism and pragmatism. Globalism seems to have lost for the moment its attractiveness and capitalism must go beyond its economic limitation. The issue of (neo)colonialism as the expression of globalization spreading still remains. Moreover, it seems that both Russia and America together with its allies identify Islamic terrorism (another "ism") as being their common enemy.

\section{Conclusions}

The analysis of the two global systems has taken into account only historical and ideological factors as determinants of the geopolitical game, leaving aside for the moment the economic and military ones, much more intensely used and therefore presumed to be more accessible and known. The empirical research of reality and then the interpretation and comparison of the data according to the mentioned factors led to the integrated conclusions, as follows:

- Both systems have emerged as a result of a confrontation and have been based on geopolitical actions. But, if at the beginning of the Cold War system, the United States and the Soviet Union were on a level playing field in world domination, five decades later, the balance of power would have been considerably in favor of Washington.

It follows that, from the perspective of the historical factor, the two systems do not overlap, their genesis being different both in context and as generating forces.

- Both systems are defined by their own ideological rainbow, but there is an element of relative continuity between the two eras, namely liberal democracy. As the 1950s and the 1960s marked the beginning of the process of finalizing the decolonization process, the ideological liberation movements of the late 1980s in Central and Eastern Europe could remain in history as the beginning of the action to complete the process of democratization worldwide. It should be emphasized, however, that if at the end of the bipolar system liberal democracy defeated (among other explanations, due to the possibility of a clear identification of the enemy), today, under the conditions of a multipolar but rather vaguely defined system, the fight is no longer clearly held between "good" and "bad" - communism has considerably lost its attractiveness, but it has not disappeared, liberal democracy is under pressure, state capitalism seems to function, Western institutional membership is competing with sentimental affinity to the East. It follows that, from the perspective of the ideological factor, each system represents the ground of ideological struggle, but each time it is carried out among other ideological forces. Considering the non-existence of a pattern of confrontation between (two) global powers, if we accept the second system's failure to comply with the model of the first, the supreme conclusion would be that Mankind is not in the face of a new Cold War. This does not mean the conflict on multiple plans, between multiple actors, including global and regional powers, is not possible. The possibility of conflict to turn into a military confrontation depends on the context.

Concerning Russia, this state will continue to play an important role in the global affairs although not quite in a manner compatible with a still Western designed international order. And as it was said, "it's not a strong Russia we should fear, but a weak one [6]"

Of course, in order to conduct a complete study, the economic and military factors should be analyzed also, so as to have a more comprehensive approach of these two international systems. This direction of research would help to better understand the manner in which an international system evolves, especially when it comes with dealing with more than two powers. 


\section{References}

[1] Michael Freeden, Ideology. A Very Short Introduction, Oxford, University Press, 2003, p.1.

[2] Henry Kissinger, The Return of History. Conflict, Migration, and Geopolitics in the Twenty-First Century, Houde of Anasi Press, 2016, p.215.

[3] Jennifer Welsh, Diplomația, București, Editura ALL, 2002, p.293.

[4] Barry Buzan, Richard Little, Sistemele internaționale în istoria lumii, Iași, Editura Polirom, 2009, p.388.

[5] Francis Fukuyama, Sfârşitul istoriei şi ultimul om, București, Editura Paideia, 1994.

[6] http://foreignpolicy.com/2016/02/17/are-we-entering-a-new-cold-war-russia-europe/. 